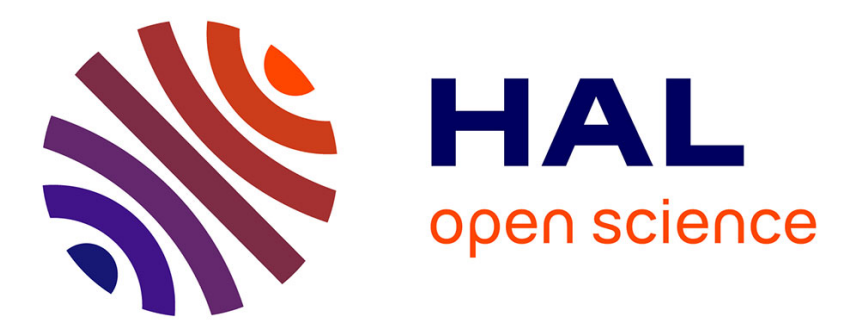

\title{
A germline oncogenic MITF mutation and tumor susceptibility
}

Brigitte Bressac-De Paillerets, Fabienne Lesueur, Corine Bertolotto

\section{To cite this version:}

Brigitte Bressac-De Paillerets, Fabienne Lesueur, Corine Bertolotto. A germline oncogenic MITF mutation and tumor susceptibility. European Journal of Cell Biology, 2014, 93 (1-2), pp.71-75. 10.1016/j.ejcb.2013.10.002 . inserm-02530572

\section{HAL Id: inserm-02530572 https://www.hal.inserm.fr/inserm-02530572}

Submitted on 20 Apr 2020

HAL is a multi-disciplinary open access archive for the deposit and dissemination of scientific research documents, whether they are published or not. The documents may come from teaching and research institutions in France or abroad, or from public or private research centers.
L'archive ouverte pluridisciplinaire HAL, est destinée au dépôt et à la diffusion de documents scientifiques de niveau recherche, publiés ou non, émanant des établissements d'enseignement et de recherche français ou étrangers, des laboratoires publics ou privés. 


\section{A germline oncogenic MITF mutation and tumour susceptibility}

Brigitte Bressac-de Paillerets ${ }^{1,2}$, Fabienne Lesueur ${ }^{3}$ and Corine Bertolotto ${ }^{4,5, \#}$

${ }^{1}$ INSERM, U946, Genetic Variation and Human Diseases Unit, Paris, France.

${ }^{2}$ Service de Génétique, Institut de Cancérologie Gustave Roussy, 94805 Villejuif, France.

${ }^{3}$ Inserm, U900, Institut Curie, Mines ParisTech, 75248 Paris cedex 05, France

${ }^{4}$ INSERM, U1065 (équipe 1), Equipe labélisée Ligue Contre le Cancer, C3M, 06204 Nice, France.

${ }^{5}$ Université of Nice Sophia-Antipolis, UFR Médecine, 06204 Nice, France.

Corresponding author: Corine Bertolotto; bertolot@unice.fr 


\begin{abstract}
MITF (Microphthalmia-associated transcription factor) is a lineage specific transcription factor that plays a critical role in melanocyte homeostasis and whose deregulation has been shown to contribute to melanoma disease. A germline mutation in MITF, impairing SUMOylation and predisposing to cutaneous malignant melanoma, was recently identified. Interestingly, an association of the MITF mutation with coexisting melanoma and renal cell carcinoma was also shown. Collectively, these data suggest that MITF has an important oncogenic function in tumorigenesis of multiple tissues/melanocytes and kidney cells.
\end{abstract}




\section{Introduction}

Cancer initiation begins when epigenetic and genetic alterations result in the production of abnormal levels of a critical protein, the production of an aberrant protein, or the complete absence of a protein that upset the normal cell function. Cancer progression can be driven by additional genetic alterations and/or environmental and lifestyle factors (Hanahan and Weinberg, 2011).

Cutaneous malignant melanoma (CMM), which derives from melanocyte transformation, represents the most deadly form of skin cancer. Its incidence has increased dramatically in white populations worldwide during the past several decades. If CMM is detected at early stages $(<1 \mathrm{~mm})$ and treated by surgical excision, individuals have better than $80 \%$ five-year survival. However, as CMM progress, they become increasingly more devastating. Indeed, $\mathrm{CMM}$ are characterized by a strong propensity to invade and metastasize. Thus, if the lesion is diagnosed at late stages, individuals will display an increased risk to develop lymph node and visceral metastases. Metastatic melanoma cannot be completely removed by surgery and melanoma metastases display extreme resistance to all types of treatment (Soengas and Lowe, 2003). Patients with metastatic melanomas have a median survival rate that typically ranges from six to ten months.

Thus, identification of cancer driver genes would help to better predict which patients might benefit from increased surveillance and earlier detection of potential dangerous lesions.

CMM is hereditary in $10 \%$ of cases. Major risk factors include a personal and familial history of melanoma, a high number of naevi/dysplasic naevi, sun exposure and reactions to sun exposure according to the phototype and mutations of $C D K N 2 A$ and $C D K 4$ (Hussussian et al., 1994; Zuo et al., 1996). Besides the rare deleterious mutations in CDKN2A and CDK4 which confer a high CMM risk, common single nucleotide polymorphisms (SNPs), in pigmenting (for example in MCIR, ASIP, MATP) or in non-pigmenting (MTAP, TERT and CASP8 for example) genes represents low-risk susceptibility alleles (Bressac-de-Paillerets et al., 2002; Fargnoli et al., 2010) (Figure 1) and could acts as modifiers of high-risk genes (Bressac-dePaillerets et al., 2002; Fargnoli et al., 2010; Law et al., 2012).

\section{MITF}

Among other genes critical for melanocyte homeostasis and melanoma disease is the microphthalmia-associated transcription factor (MITF). MITF belongs to the Myc supergene family of basic-helix-loop-helix leucine zipper (b-HLH-LZ) transcription factor considered as the "master gene" of melanocyte homeostasis (Steingrimsson et al., 2004). MITF loss-of- 
function mutations are responsible for inherited disorders in neural crest cell development, the type 2a Waardenburg and Tietz syndromes characterized by melanocyte loss and pigmentary defects (Pingault et al., 2010). In adulthood, MITF is involved in the maintenance of melanocyte stem cells (Hou et al., 2000; Nishimura et al., 2004) and controls melanocyte differentiation (Bertolotto et al., 1998a; Bertolotto et al., 1996; Bertolotto et al., 1998b). Recent findings indicate that MITF also plays a key role in the pathogenesis of CMM. Indeed, MITF is amplified in 10-20\% of CMM cases and this amplification is associated with a decreased 5-year survival (Garraway et al., 2005). In addition, MITF triggers transformation of immortalized melanocytes in cooperation with $\mathrm{BRAF}^{\mathrm{V} 600 \mathrm{E}}$, an activating mutation commonly found in melanocytic lesions (Davies et al., 2002; Garraway et al., 2005). At the transcriptional level, MITF controls genes involved in cell survival (BCL2, HIF1A, BCL2A1), migration (DIAPH1, MET) and proliferation (CDK2, TBX2, CDKN1B) (Carreira et al., 2006; Cheli et al., 2010). Implication of MITF in these various biological processes might be linked to its level and activity ensuing post-transcriptional regulation as proposed by the group of C. Goding (Carreira et al., 2006). Consistent with the notion that MITF provides important signals for proliferation of melanoma cells, we have recently shown that sustained inhibition of MITF induces a G0/G1 growth arrest and their entry into senescence (Giuliano et al., 2010; Giuliano et al., 2011; Strub et al., 2011), a program associated with the cessation of the proliferation potential (Collado et al., 2007).

\section{The MITF p.E318K missense substitution in cancer}

\section{- Melanoma}

By sequencing the entire coding sequence of MITF in a highly selected set of patients presenting either with a strong family history of CMM or multiple primary melanomas, we identified a recurrent germline missense substitution p.E318K (c.952G>A, NM_000248.3), occurring at a significantly higher frequency in the at-risk patients than in the control population (Bertolotto et al., 2011). Concomitantly to our study, whole genome sequencing of probands in a large melanoma-prone family identified the same recurrent inherited mutation (Yokoyama et al., 2011). The variant cosegregated with CMM in some but not all cases in the family, indicating a possible intermediate-risk variant. Consistent with this, the variant was found to double the risk of CMM for carriers in a large Australian population-based casecontrol study $(\mathrm{OR}=2.33,95 \% \mathrm{CI}(1.21-4.70))$ and a similar effect was seen in a case-control study in the United Kingdom (Yokoyama et al., 2011). The mutation is very rare in the general population (allele frequency of 0.003 in the French population; 0.0072 in the 
Australian population, and 0.0085 in the UK population). Subsequently, the MITF E318K variant was found in a group of Italian melanoma patients (Ghiorzo et al., 2013) and in another Australian study (Sturm et al., 2013) with similar allele frequency (Figure 1). All these studies show that the MITF E318K variant is enriched in those with multiple primary melanomas or a family history of melanomas. We have also examined the prevalence of the MITF E318K mutation in 10 European populations by genotyping over 1,100 sporadic CMM cases (essentially with single primary melanoma) and 1,500 matched controls from the prospective cohorts EPIC (European Prospective Investigation into Cancer and Nutrition) (Riboli E. The European Prospective Investigation into Cancer and Nutrition (EPIC): plans and progress. J Nutr. 2001 Jan;131(1):170S-175S. Review) and E3N (Etude Epidémiologique auprès de femmes de la Mutuelle Générale de l'Education Nationale) (Nutrition, hormones et cancer: épidémiologie et prévention. ERI 20. L'étude E3N, website: http://www.e3n.fr/). Although the mutation frequency was lower than in the previous studies $(<0.002)$, carriers were significantly over-represented in sporadic CMM cases (Pertesi, Lesueur et al. manuscript in preparation).

\section{- Kidney cancer}

Epidemiological studies show that patients with melanoma had an increased risk of developing secondary tumours including renal cancer (RCC) (Bradford et al., 2010; SchmidWendtner et al., 2001; Wu et al., 2006). Additionally, a significant increased risk of developing melanoma has been pinpointed in patients affected by a kidney cancer (Beisland et al., 2006). Other lines of evidence are in favor of a genetic predisposition to the coexistence of melanoma and kidney cancer (Maubec et al., 2010). However, known risk factors for RCC are smoking, obesity and hypertension and no common genetic factors so far could explain this predisposition. Because of lack of specific symptoms at early stage, kidney cancer is often diagnosed late, thereby favoring more aggressive and therapy resistant tumors. Therefore, there is an urgent need to find diagnostic and prognostic markers for renal cancers.

Although MITF's role in kidney physiopathology remains to be determined, MITF stimulates the transcription, among others, of hypoxia inducible factor HIF1A (HIF1A), which is targeted by all known kidney cancer predisposing genes, (namely, the tumor suppressor genes VHL, FLCN, FH, SDHB, TSC1 and TSC2 and the oncogene MET) (Busca et al., 2005; Linehan et al., 2010). MITF also controls transcription of MET directly (Beuret et al., 2011). We therefore sequenced MITF in patients with kidney cancers. The germline p.E318K mutation was also detected, in at-risk patients having developed RCC or both CMM and 
RCC, at a significantly higher frequency, than in the control population. Data from these studies indicate that the missense variant p.E318K is more often observed in patients affected by multiple primary cancers, such as melanoma+RCC (Bertolotto et al., 2011; Ghiorzo et al., 2013) or by multiple primary melanomas (Bertolotto et al., 2011; Ghiorzo et al., 2013; Yokoyama et al., 2011) and associated ORs ranged from 4.22, 95\%CI $(1.52,10.91)$ [Australian study], 7.79, 95\%CI $(3.12,20.04)$ [French study] and 6.40, 95\%CI $(1.43,28.58)$ [Italian study] for multiple melanomas to 14.46 , 95\%CI $(3.74,48.04)$ [French study] for melanoma+RCC. An association of this variant with kidney cancer has also been found in the Italian study (Ghiorzo et al., 2013).

Collectively, MITF might be the missing link between melanoma and kidney cancer and as the first common inherited factor between these two cancers (Bertolotto et al., 2011).

\section{MITF family and renal cancer}

MITF belongs to a subfamily of bHLH-LZ transcription factor, called the MiT family, which also includes TFE3 and TFEB. These two transcription factors shares sequence homology in their DNA-contacting basic domains and the transactivation domains and recognized similar DNA sequences, indicating potential overlap in their target gene repertoire. Additionally, these factors can heterodimerize with each other (Steingrimsson et al., 2002).

Up to date, reports from the literature indicate that TFE3 and TFEB play predominant roles in renal cell carcinoma and MITF in melanoma pathogenesis, although functional redundancy has been reported (Davis et al., 2006). TFE3 fusions with the PRCC, NonO, SFP or ASPL genes have been identified in 30 to $50 \%$ of paediatric renal carcinomas (Argani et al., 2003; Davis and Fisher, 2007; Tsuda et al., 2007; Weterman et al., 2000) and TFEB translocation leading to promoter exchange with that of the alpha gene has been reported in a subset of pediatric renal neoplasms (Davis et al., 2003). As mentioned above, MITF is amplified in 10 to $20 \%$ of melanomas and this amplification has been associated with a poor prognostic (Garraway et al., 2005). Somatic MITF mutations, which biological consequences remain to be determined, have been reported in melanoma samples (Cronin et al., 2009). The association of the MITF E318K mutation with melanoma and kidney cancer provide the first demonstration of MITF implication in kidney cancer. Altogether, MITF is the third member of the MiT family that might play a critical role in kidney cancer.

Patients affected with melanoma or renal cell carcinoma (RCC) show an excess of second primary malignancies, including RCC for melanoma patients and melanoma for RCC patients (Beisland et al., 2006; Schmid-Wendtner et al., 2001). Because genetic and functional data 
demonstrate that MITF p.E318K is a rare oncogenic germline substitution and an inherited factor predisposing to both cancer, such association may represent a new inherited tumour syndrome.

\section{MITF, SUMOylation and cancer}

Two sumoylation sites, one in the N-terminal region and the other in the C-terminal region, have been identified in the MITF sequence and shown to regulate MITF sumoylation and transcriptional activity (Miller et al., 2005; Murakami and Arnheiter, 2005). The nonsynonymous c. $952 \mathrm{G}>\mathrm{A}$ substitution changes the glutamic acid at codon 318 into a lysine. This substitution changes the SUMOylation consensus binding site IKQE in the C-terminal part of MITF for the IKQK sequence (Mi-E318K) and reduces MITF sumyolation (Bertolotto et al., 2011) (Figure 2).

SUMOylation is an ubiquitination-like post-translational modification triggering covalent SUMO attachment to target proteins (Wilkinson and Henley, 2010). SUMO-proteins are essential for the function of eukaryotic cells, as deletion of the SUMO-1 homologue, smt3, in yeast causes loss of cell viability and mice knock out for UBC9 can die at early embryonic stages (Giaever et al., 2002; Nacerddine et al., 2005).

SUMOylation has been reported to affect protein cellular localization, stability and transcriptional activity of proteins. In this regard, a relationship between dysregulation of the SUMO-pathway and human diseases, neurodegenerative and heart diseases, and cancers, has been pointed out. Mutations of proteins such as huntingtin, APP, a-synuclein, DJ-1, tau, Ataxin-1 in neurological disorders, or mutations of NKX2-5 in heart diseases displayed impaired SUMOylation (Kim et al., 2011; Sarge and Park-Sarge, 2011). However, mutations in these proteins have not been reported to affect SUMO-binding sites, rendering difficult to determine the etiologic role of SUMOylation in the diseases. Sumoylation has also likely roles in cancer. The level of SUMO enzymes, UBC9, PIAS3 and SUMO-E1 is enhanced in a number of human cancers and has been associated with bad outcomes (Mo et al., 2005; Wang et al., 2011). Altered expression of SUMO-proteases (SENP) is also observed in cancers (Bawa-Khalfe and Yeh, 2010). Relevant to these observations, SUMOylation targets several factors such as p53, pRb, BRCA1, which deregulated activities are critical for tumor progression (Morris et al., 2009). Once again, how SUMO-modification is involved in tumorigenesis remains to be clearly demonstrated. Up to date, only one study provided solid evidence that the SUMOylation status of a protein directly impacts on human health. LaminA mutations in familial dilated-cardiomyopathies affect a SUMOylation consensus site 
leading to change of the sequence MKEE into MKEG or MKEK. The glutamic acid position is critical for SUMOylation at the preceding lysine residue in the consensus sequence. In this regard, the two substitutions of lamin-A caused significant decrease in SUMOylation and an altered pattern of lamin-A localization and nuclear morphology associated with increased cell death (Zhang and Sarge, 2008).

Therefore, our findings provide the first direct evidence of SUMO modification role in cancer.

The molecular mechanisms by which MITF E318K mediates its effect remain to be fully elucidated. Analysis of genome wide occupancy reveals a global increase in MITF E318K-occupied loci coupled with the existence of sites exclusively bound by the mutant protein, indicating that SUMOylation-deficient MITF E318K protein may therefore result in the regulation of distinct sets of genes. Furthermore, transcriptomic analyses indicate that MITF E318K signature is related to cell growth, proliferation and inflammation. In line with these observations, MITF E318K enhances the migrative and invasive properties of melanoma and renal carcinoma cells and increases the ability to form colonies of immortalized melanocytes, hence demonstrating that MITF E318K displays pro-tumoral properties (Bertolotto et al., 2011).

In conclusion, the MITF E318K mutation represents a gain of function mutation. By showing that MITF E318K is endowed with pro-tumoral properties, our results reinforce the notion that MITF might act as an oncogene of the melanocyte lineage in some circumstances. Moreover, our findings highlight for the first time the role of MITF in kidney cancer, in which, three other MITF-related members have been already involved. 


\section{References}

Argani, P., Lui, M.Y., Couturier, J., Bouvier, R., Fournet, J.C., and Ladanyi, M., 2003. A novel CLTC-TFE3 gene fusion in pediatric renal adenocarcinoma with $t(X ; 17)(p 11.2 ; q 23)$. Oncogene 22, 5374-5378.

Bawa-Khalfe, T., and Yeh, E.T., 2010. SUMO Losing Balance: SUMO Proteases Disrupt SUMO Homeostasis to Facilitate Cancer Development and Progression. Genes \& cancer 1, 748-752.

Beisland, C., Talleraas, O., Bakke, A., and Norstein, J., 2006. Multiple primary malignancies in patients with renal cell carcinoma: a national population-based cohort study. BJU international 97, 698-702.

Bertolotto, C., Abbe, P., Hemesath, T.J., Bille, K., Fisher, D.E., Ortonne, J.P., and Ballotti, R., 1998a. Microphthalmia gene product as a signal transducer in cAMP-induced differentiation of melanocytes. J Cell Biol 142, 827-835.

Bertolotto, C., Bille, K., Ortonne, J.P., and Ballotti, R., 1996. Regulation of tyrosinase gene expression by cAMP in B16 melanoma cells involves two CATGTG motifs surrounding the TATA box: implication of the microphthalmia gene product. J Cell Biol 134, 747-755.

Bertolotto, C., Busca, R., Abbe, P., Bille, K., Aberdam, E., Ortonne, J.P., and Ballotti, R., 1998b. Different cis-acting elements are involved in the regulation of TRP1 and TRP2 promoter activities by cyclic AMP: pivotal role of $M$ boxes (GTCATGTGCT) and of microphthalmia. Mol Cell Biol 18, 694-702.

Bertolotto, C., Lesueur, F., Giuliano, S., Strub, T., de Lichy, M., Bille, K., Dessen, P., d'Hayer, B., Mohamdi, H., Remenieras, A., et al.,2011. A SUMOylation-defective MITF germline mutation predisposes to melanoma and renal carcinoma. Nature 480, 94-98.

Beuret, L., Ohanna, M., Strub, T., Allegra, M., Davidson, I., Bertolotto, C., and Ballotti, R., 2011. BRCA1 is a new MITF target gene. Pigment Cell Melanoma Res 24, 725-727.

Bradford, P.T., Freedman, D.M., Goldstein, A.M., and Tucker, M.A., 2010. Increased risk of second primary cancers after a diagnosis of melanoma. Arch Dermatol 146, 265-272.

Bressac-de-Paillerets, B., Avril, M.F., Chompret, A., and Demenais, F., 2002. Genetic and environmental factors in cutaneous malignant melanoma. Biochimie 84, 67-74.

Busca, R., Berra, E., Gaggioli, C., Khaled, M., Bille, K., Marchetti, B., Thyss, R., Fitsialos, G., Larribere, L., Bertolotto, C., et al., 2005. Hypoxia-inducible factor 1 \{alpha\} is a new target of microphthalmia-associated transcription factor (MITF) in melanoma cells. J Cell Biol.

Carreira, S., Goodall, J., Denat, L., Rodriguez, M., Nuciforo, P., Hoek, K.S., Testori, A., Larue, L., and Goding, C.R., 2006. Mitf regulation of Dial controls melanoma proliferation and invasiveness. Genes Dev 20, 3426-3439.

Cheli, Y., Ohanna, M., Ballotti, R., and Bertolotto, C., 2010. Fifteen-year quest for microphthalmia-associated transcription factor target genes. Pigment Cell Melanoma Res 23, 27-40.

Collado, M., Blasco, M.A., and Serrano, M., 2007. Cellular senescence in cancer and aging. Cell 130, 223-233.

Cronin, J.C., Wunderlich, J., Loftus, S.K., Prickett, T.D., Wei, X., Ridd, K., Vemula, S., Burrell, A.S., Agrawal, N.S., Lin, J.C., et al., 2009. Frequent mutations in the MITF pathway in melanoma. Pigment Cell Melanoma Res 22, 435-444.

Davies, H., Bignell, G.R., Cox, C., Stephens, P., Edkins, S., Clegg, S., Teague, J., Woffendin, H., Garnett, M.J., Bottomley, W., et al., 2002. Mutations of the BRAF gene in human cancer. Nature 417, 949-954.

Davis, I.J., and Fisher, D.E., 2007. MiT transcription factor associated malignancies in man. Cell Cycle 6, 1724-1729. 
Davis, I.J., Hsi, B.L., Arroyo, J.D., Vargas, S.O., Yeh, Y.A., Motyckova, G., Valencia, P., Perez-Atayde, A.R., Argani, P., Ladanyi, M., et al., 2003. Cloning of an Alpha-TFEB fusion in renal tumors harboring the $\mathrm{t}(6 ; 11)(\mathrm{p} 21 ; \mathrm{q} 13)$ chromosome translocation. Proc Natl Acad Sci U S A 100, 6051-6056.

Davis, I.J., Kim, J.J., Ozsolak, F., Widlund, H.R., Rozenblatt-Rosen, O., Granter, S.R., Du, J., Fletcher, J.A., Denny, C.T., Lessnick, S.L., et al., 2006. Oncogenic MITF dysregulation in clear cell sarcoma: defining the MiT family of human cancers. Cancer Cell 9, 473-484.

Fargnoli, M.C., Gandini, S., Peris, K., Maisonneuve, P., and Raimondi, S., 2010. MC1R variants increase melanoma risk in families with CDKN2A mutations: a meta-analysis. Eur $\mathrm{J}$ Cancer 46, 1413-1420.

Garraway, L.A., Widlund, H.R., Rubin, M.A., Getz, G., Berger, A.J., Ramaswamy, S., Beroukhim, R., Milner, D.A., Granter, S.R., Du, J., et al., 2005. Integrative genomic analyses identify MITF as a lineage survival oncogene amplified in malignant melanoma. Nature 436, 117-122.

Ghiorzo, P., Pastorino, L., Queirolo, P., Bruno, W., Tibiletti, M.G., Nasti, S., Andreotti, V., Paillerets, B.B., and Bianchi Scarra, G., 2013. Prevalence of the E318K MITF germline mutation in Italian melanoma patients: associations with histological subtypes and family cancer history. Pigment Cell Melanoma Res 26, 259-262.

Giaever, G., Chu, A.M., Ni, L., Connelly, C., Riles, L., Veronneau, S., Dow, S., LucauDanila, A., Anderson, K., Andre, B., et al., 2002. Functional profiling of the Saccharomyces cerevisiae genome. Nature 418, 387-391.

Giuliano, S., Cheli, Y., Ohanna, M., Bonet, C., Beuret, L., Bille, K., Loubat, A., Hofman, V., Hofman, P., Ponzio, G., et al., 2010. Microphthalmia-associated transcription factor controls the DNA damage response and a lineage-specific senescence program in melanomas. Cancer Res 70, 3813-3822.

Giuliano, S., Ohanna, M., Ballotti, R., and Bertolotto, C. (2011). Advances in melanoma senescence and potential clinical application. Pigment Cell Melanoma Res In press.

Hanahan, D., and Weinberg, R.A., 2011. Hallmarks of cancer: the next generation. Cell 144, 646-674.

Hou, L., Panthier, J.J., and Arnheiter, H., 2000. Signaling and transcriptional regulation in the neural crest-derived melanocyte lineage: interactions between KIT and MITF. Development 127, 5379-5389.

Hussussian, C.J., Struewing, J.P., Goldstein, A.M., Higgins, P.A., Ally, D.S., Sheahan, M.D., Clark, W.H., Jr., Tucker, M.A., and Dracopoli, N.C., 1994. Germline p16 mutations in familial melanoma. Nat Genet 8, 15-21.

Kim, E.Y., Chen, L., Ma, Y., Yu, W., Chang, J., Moskowitz, I.P., and Wang, J., 2011. Expression of sumoylation deficient $\mathrm{Nkx} 2.5$ mutant in $\mathrm{Nkx} 2.5$ haploinsufficient mice leads to congenital heart defects. PloS one 6, e20803.

Law, M.H., Macgregor, S., and Hayward, N.K., 2012. Melanoma genetics: recent findings take us beyond well-traveled pathways. J Invest Dermatol 132, 1763-1774.

Linehan, W.M., Bratslavsky, G., Pinto, P.A., Schmidt, L.S., Neckers, L., Bottaro, D.P., and Srinivasan, R. (2010). Molecular diagnosis and therapy of kidney cancer. Annual review of medicine 61, 329-343.

Maubec, E., Chaudru, V., Mohamdi, H., Grange, F., Patard, J.J., Dalle, S., Crickx, B., Paillerets, B.B., Demenais, F., and Avril, M.F., 2010. Characteristics of the coexistence of melanoma and renal cell carcinoma. Cancer 116, 5716-5724.

Miller, A.J., Levy, C., Davis, I.J., Razin, E., and Fisher, D.E., 2005. Sumoylation of MITF and its related family members TFE3 and TFEB. J Biol Chem 280, 146-155.

Mo, Y.Y., Yu, Y., Theodosiou, E., Ee, P.L., and Beck, W.T., 2005. A role for Ubc9 in tumorigenesis. Oncogene 24, 2677-2683. 
Morris, J.R., Boutell, C., Keppler, M., Densham, R., Weekes, D., Alamshah, A., Butler, L., Galanty, Y., Pangon, L., Kiuchi, T., et al., 2009. The SUMO modification pathway is involved in the BRCA1 response to genotoxic stress. Nature 462, 886-890.

Murakami, H., and Arnheiter, H., 2005. Sumoylation modulates transcriptional activity of MITF in a promoter-specific manner. Pigment Cell Res 18, 265-277.

Nacerddine, K., Lehembre, F., Bhaumik, M., Artus, J., Cohen-Tannoudji, M., Babinet, C., Pandolfi, P.P., and Dejean, A., 2005. The SUMO pathway is essential for nuclear integrity and chromosome segregation in mice. Dev Cell 9, 769-779.

Nishimura, E.K., Granter, S.R., and Fisher, D.E., 2004. Mechanisms of Hair Graying: Incomplete Melanocyte Stem Cell Maintenance in the Niche. Science.

Pingault, V., Ente, D., Dastot-Le Moal, F., Goossens, M., Marlin, S., and Bondurand, N., 2010. Review and update of mutations causing Waardenburg syndrome. Hum Mutat 31, 391406.

Sarge, K.D., and Park-Sarge, O.K., 2011. SUMO and its role in human diseases. International review of cell and molecular biology 288, 167-183.

Schmid-Wendtner, M.H., Baumert, J., Wendtner, C.M., Plewig, G., and Volkenandt, M., 2001. Risk of second primary malignancies in patients with cutaneous melanoma. $\mathrm{Br} \mathrm{J}$ Dermatol 145, 981-985.

Soengas, M.S., and Lowe, S.W., 2003. Apoptosis and melanoma chemoresistance. Oncogene 22, 3138-3151.

Steingrimsson, E., Copeland, N.G., and Jenkins, N.A., 2004. Melanocytes and the microphthalmia transcription factor network. Annu Rev Genet 38, 365-411.

Steingrimsson, E., Tessarollo, L., Pathak, B., Hou, L., Arnheiter, H., Copeland, N.G., and Jenkins, N.A., 2002. Mitf and Tfe3, two members of the Mitf-Tfe family of bHLH-Zip transcription factors, have important but functionally redundant roles in osteoclast development. In Proc Natl Acad Sci U S A, pp. 4477-4482.

Strub, T., Giuliano, S., Ye, T., Bonet, C., Keime, C., Kobi, D., Le Gras, S., Cormont, M., Ballotti, R., Bertolotto, C., et al., 2011. Essential role of microphthalmia transcription factor for DNA replication, mitosis and genomic stability in melanoma. Oncogene 30, 2319-2332.

Sturm, R.A., Fox, C., McClenahan, P., Jagirdar, K., Ibarrola-Villava, M., Banan, P., Abbott, N.C., Ribas, G., Gabrielli, B., Duffy, D.L., et al., 2013. Phenotypic Characterization of Nevus and Tumor Patterns in MITF E318K Mutation Carrier Melanoma Patients. J Invest Dermatol. Tsuda, M., Davis, I.J., Argani, P., Shukla, N., McGill, G.G., Nagai, M., Saito, T., Lae, M., Fisher, D.E., and Ladanyi, M., 2007. TFE3 fusions activate MET signaling by transcriptional up-regulation, defining another class of tumors as candidates for therapeutic MET inhibition. Cancer Res 67, 919-929.

Wang, X.D., Lapi, E., Sullivan, A., Ratnayaka, I., Goldin, R., Hay, R., and Lu, X., 2011. SUMO-modified nuclear cyclin D1 bypasses Ras-induced senescence. Cell Death Differ 18, 304-314.

Weterman, M.J., van Groningen, J.J., Jansen, A., and van Kessel, A.G., 2000. Nuclear localization and transactivating capacities of the papillary renal cell carcinoma-associated TFE3 and PRCC (fusion) proteins. Oncogene 19, 69-74.

Wilkinson, K.A., and Henley, J.M., 2010. Mechanisms, regulation and consequences of protein SUMOylation. Biochem J 428, 133-145.

Wu, Y.H., Kim, G.H., Wagner, J.D., Hood, A.F., and Chuang, T.Y., 2006. The association between malignant melanoma and noncutaneous malignancies. International journal of dermatology 45, 529-534.

Yokoyama, S., Woods, S.L., Boyle, G.M., Aoude, L.G., MacGregor, S., Zismann, V., Gartside, M., Cust, A.E., Haq, R., Harland, M., et al., 2011. A novel recurrent mutation in MITF predisposes to familial and sporadic melanoma. Nature 480, 99-103. 
Zhang, Y.Q., and Sarge, K.D., 2008. Sumoylation regulates lamin A function and is lost in lamin A mutants associated with familial cardiomyopathies. J Cell Biol 182, 35-39.

Zuo, L., Weger, J., Yang, Q., Goldstein, A.M., Tucker, M.A., Walker, G.J., Hayward, N., and Dracopoli, N.C., 1996. Germline mutations in the p16INK4a binding domain of CDK4 in familial melanoma. Nat Genet 12, 97-99. 


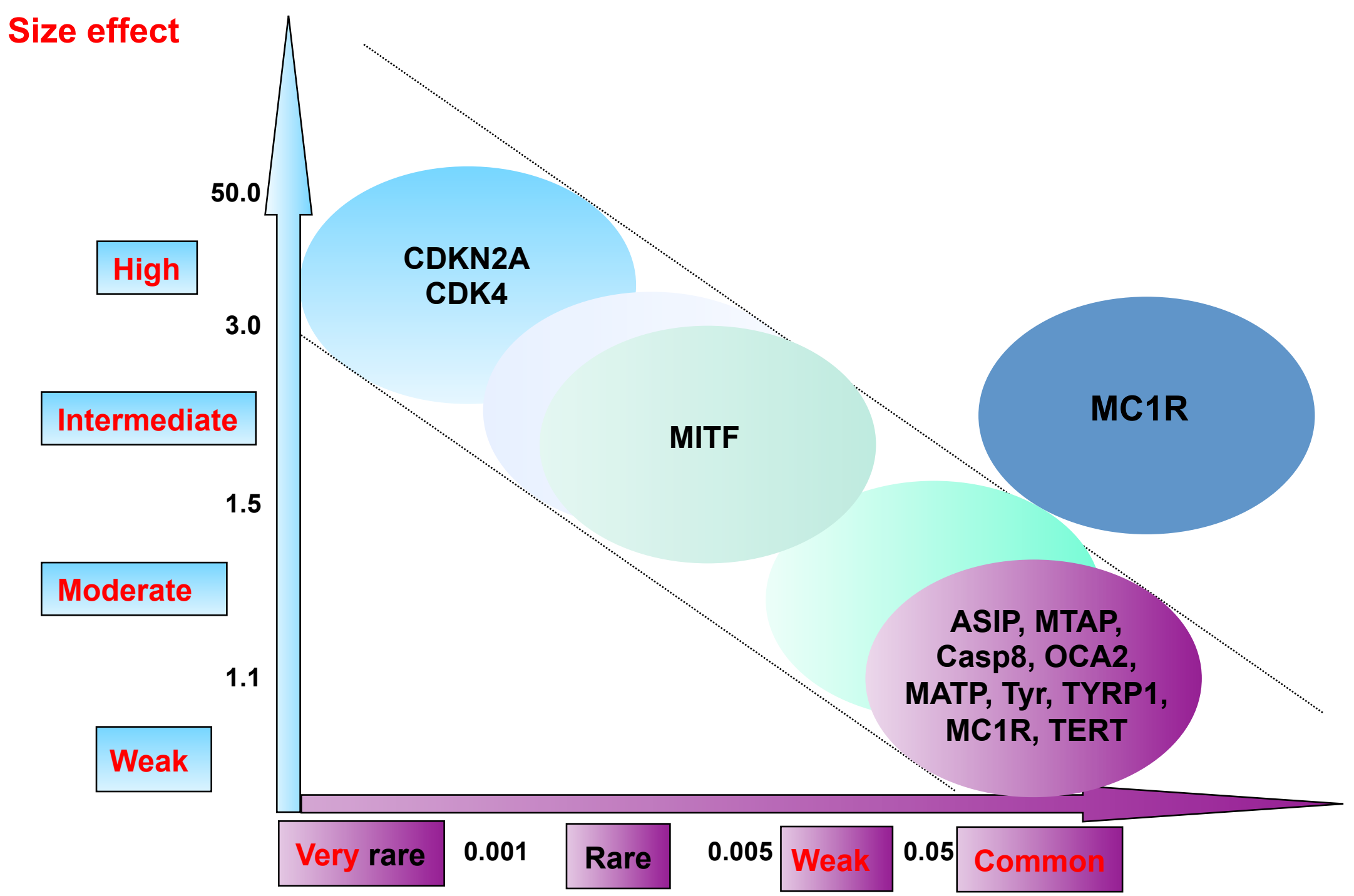

Minor allele frequency 
A

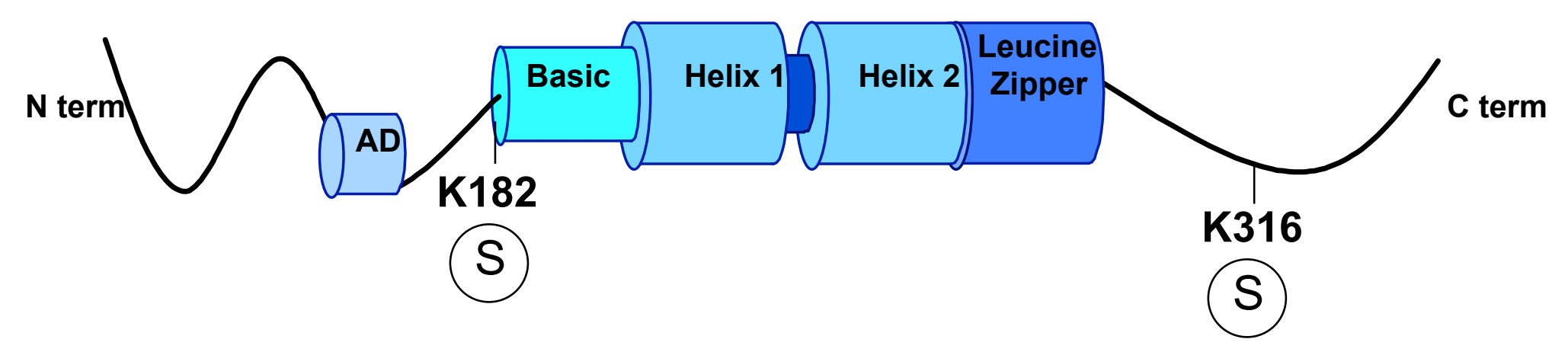

B

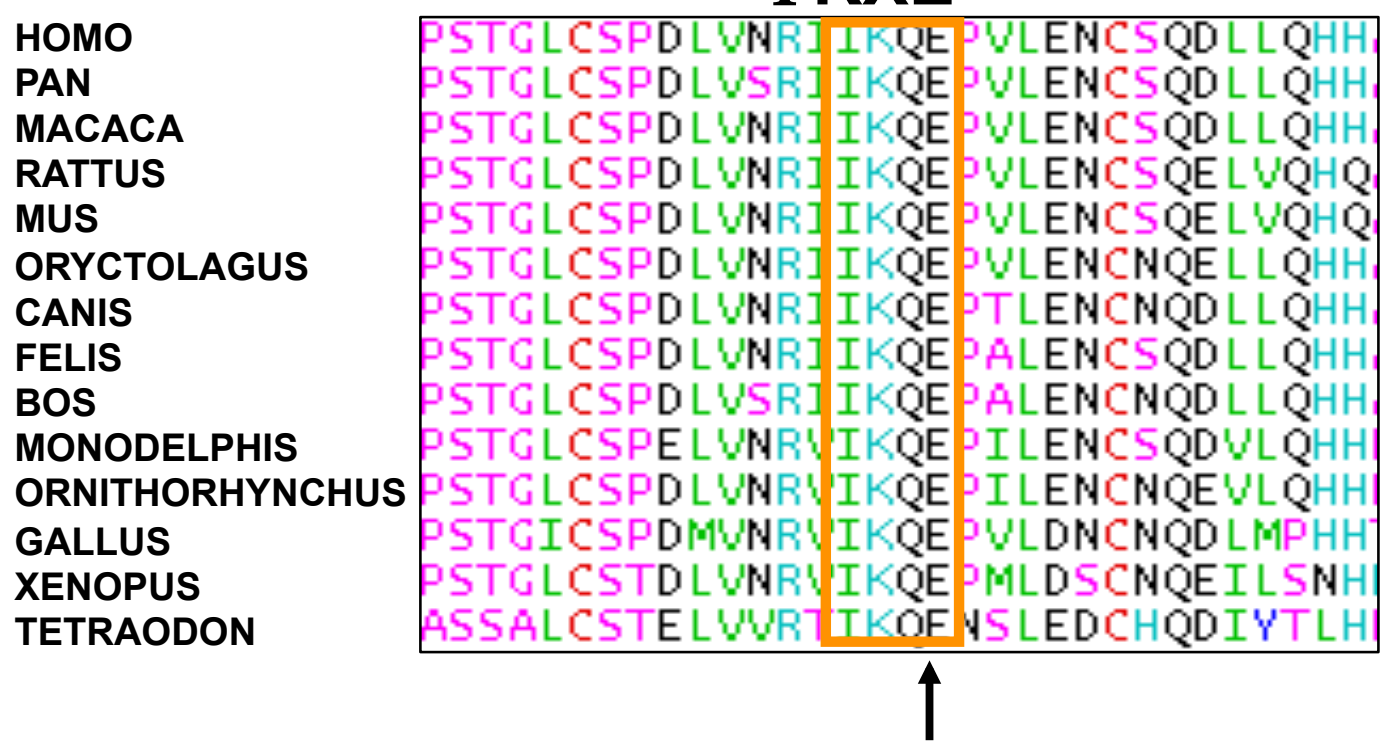

C

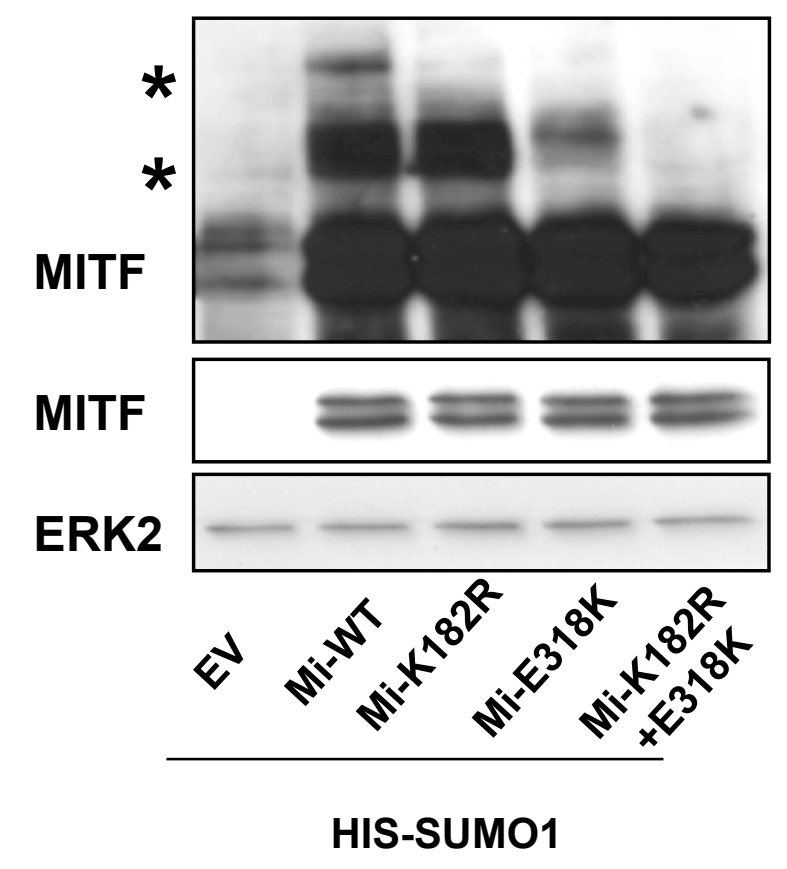

